\title{
Functional anatomy of five endangered tropical timber wood species of the family Dipterocarpaceae
}

\author{
Rumana Rana $\cdot$ Rosemarie Langenfeld-Heyser • \\ Reiner Finkeldey • Andrea Polle
}

Received: 13 July 2008/Revised: 18 October 2008/Accepted: 13 November 2008/Published online: 3 December 2008

(C) The Author(s) 2008. This article is published with open access at Springerlink.com

\begin{abstract}
Wood anatomy of five dipterocarp species endemic to the Philippines was studied with the goal to explore functional wood traits of ecological significance. Stem wood of 6-year-old trees grown under similar environmental conditions in a plantation (Leyte, Philippines) was used. Wood densities decreased in the following order Hopea plagata $>$ Dipterocarpus kerrii > Parashorea malaanoman $>$ Shorea almon $\approx$ Shorea contorta. This was mainly caused by significantly thicker fiber cell walls of $H$. plagata and D. kerrii than those of the other three species. Wood density was negatively correlated with the abundance of axial parenchyma cells. Predicted conductance was independent from wood density and lowest in $H$. plataga and highest in D. kerrii and S. contorta. These results indicate that $H$. plagata and $D$. kerrii is woods have higher constructions costs in term of carbon per unit of biomass, and that $H$. plagata is probably better acclimated to varying soil moisture than the other species.
\end{abstract}

Keywords Dipterocarps - Anatomical traits · Hydraulic system · Xylem

Communicated by M. Zwieniecki.

R. Rana $\cdot$ R. Langenfeld-Heyser $\cdot$ A. Polle $(\bowtie)$ Forstbotanik und Baumphysiologie, Büsgen-Institut, Büsgenweg 2, 37077 Göttingen, Germany

e-mail: apolle@gwdg.de

R. Finkeldey

Forstgenetik und Forstpflanzenzüchtung, Büsgen-Institut,

Büsgenweg 2, 37077 Göttingen, Germany

\section{Introduction}

Most tropical forests in Southeast Asia are dominated by Dipterocarpaceae. The members of this family are especially abundant in lowland forests and most of them are valuable timber species. However, due to the destruction of tropical rain forests, they disappear at an alarming rate (FAO 2007). In the Philippines, only 3\% of the land area is still covered by primary forests, and very few natural dipterocarp forests are left, although the islands are one of the most important biodiversity hotspots of the world (Myers et al. 2000). Economically important genera such as Dipterocarpus, Parashorea and Shorea have been classified as critically endangered species (IUNC 2007). Nowadays, a logging ban prohibits cutting of trees on the Philippines and reforestation trials with native species are being made. However, documentation and analysis of success of these measures is scarce (Langenberger 2006), and information on anatomical traits relevant for the ecological requirements of many tree species is lacking.

Tissue traits such as wood density and the hydraulic architecture of plant species are informative for land-plant ecology (Westoby and Wright 2006; Swenson and Enquist 2007). With respect to water transport, wood properties such as vessel dimensions and lumen area are relevant (Preston et al. 2006). Conductivity increases with the fourth power of radius and only linearly with vessel number. Therefore, vessel size is a far more important parameter determining hydraulic characteristics than vessel number (Tyree and Zimmermann 2002). It has been suspected that large vessels are more prone to cavitation than smaller ones; however, this is still unclear. Correlations appear to exist between cavitation resistance and wood density (Hacke and Sperry 2001; Hacke et al. 2001, 
2006). In some tropical tree species, conductivity was found to vary with density (Christensen-Dalsgaard et al. 2007a).

Tropical tree species cover a wide range of wood densities from 0.3 to $1.2 \mathrm{~g} \mathrm{~cm}^{-3}$ (Ketterings et al. 2001, Wood density database 2007). However, saplings of shade-tolerant trees may spend years growing slowly in the understory, only to grow into a tall reproductive adult when supplied by a gap in the canopy. The wood anatomy and hydraulic properties of juvenile trees may, therefore, differ from features found in large adults. In emergent tropical trees, thin-walled fibers are more typical for rapidly growing, early succession species and thick-walled fibers are more common in climax species (Swaine and Whitemore 1988). The fibers in the wood matrix appear to contribute directly to biomechanical strength and offer support against implosion (Baas et al. 2004; Berry and Roderick 2005; Jacobson et al. 2005).

Dipterocarps are characterized by a high diversity of wood anatomy (Gottwald and Parameswaran 1966; Lomibao 1973; Ashton 1982; Ella and Meniado 1992; Newman et al. 1996). While members of the tribe Dipterocarpae are characterized by solitary vessels, scattered resin canals and fibers with bordered pits, members of the Shoreae (Hopea, Shorea and Parashorea) have grouped vessels and resin canals in tangential bands (Ashton 1982). Furthermore, abundant parenchyma is typical for tropical forest tree species with high photosynthetic rates (Alves and Angyalossy-Alfonso 2002). The combination of abundant parenchyma with septate fiber gives a huge potential for carbon and water storage in the wood of these species (Baas et al. 2004).

In the present study, we investigated wood anatomy of five dipterocarp species endemic to the Philippines grown in an experimental plantation. The main goal was to explore wood traits important for the hydraulic system. The species studied here represent three timber groups, i.e., Apitong (Dipterocarpus kerrii), Yakal (Hopea plagata), and Philippine mahagony (Parashorea malaanoman, Shorea almon, Shorea contorta), which differ in wood densities and utilization purposes (Newman et al. 1996). Despite anatomical work on many dipterocarps (Gottwald and Parameswaran 1966), quantitative anatomical analyses indicative for wood functions are still lacking. In the Philippine lowland forests, dry periods occur annually and are particularly severe and long-lasting during El Niño events. These events threaten the establishment of restoration plantations (Slik 2004). To obtain information with respect to potential differences in hydraulic properties and water requirements, we investigated functional wood anatomy in young plantation trees.

\section{Materials and methods}

Field site and sampling

A plantation with five dipterocarp species (Dipterocarpus kerrii King Damar, H. plagata (Blanco) S. Vidal, Parashorea malaanoman (Blanco) Merr, Shorea almon Foxw and Shorea contorta Vidal) was installed at the western foothills of Mt. Pangasugan, within the forest reserve of the Leyte State University (Leyte, Philippines, $9^{\circ} 55^{\prime} \mathrm{N}$ to $11^{\circ} 48^{\prime} \mathrm{N}$ and $124^{\circ} 17^{\prime} \mathrm{E}$ to $125^{\circ} 18^{\prime} \mathrm{E}$ ). The local climate data from a weather station of the Philippines Atmospheric, Geophysical and Astronomical Service Administration (PAGASA, 7 m.a.s.l.) on the campus of the Leyte State University showed a mean annual temperature of $27.4^{\circ} \mathrm{C}$ and mean sum of annual precipitation of $2,586 \mathrm{~mm}$ (Langenberger 2003). The wettest months are NovemberJanuary with a mean monthly precipitation of about $290 \mathrm{~mm}$. The driest months are March-May with an average monthly precipitation of $95-133 \mathrm{~mm}$ (Langenberger 2003).

Five individual trees of each of the five species were felled after 6 years with the following mean heights: Dipterocarpus kerrii $(8.6 \pm 0.9 \mathrm{~m}), \quad H . \quad$ plagata $(9.6 \pm 1.1 \mathrm{~m})$, Parashorea malaanoman $(7.2 \pm 0.8 \mathrm{~m})$, Shorea almon $(4.1 \pm 0.5 \mathrm{~m})$, Shorea contorta $(9.8 \pm$ $1.3 \mathrm{~m}$ ). Two stem disks (thickness about $3 \mathrm{~cm}$ each) were immediately excised from each tree at $1.3 \mathrm{~m}$ above ground: one was sealed in plastic and later stored air dried, and the other was preserved in $70 \%$ ethanol for anatomical analyses. Wood densities were determined by the Archimedes' principle (Hacke et al. 2000) by transferring samples (half disks without bark or pith) that had been stored sealed in plastic during transportation to a water-containing vessel placed on a balance. The weight change recorded during submersion corresponded to the mass of water displaced. The volume was calculated as: displacement weight $/ D$ where $D=$ density of water at $20^{\circ} \mathrm{C}\left(0.998 \mathrm{~kg} \mathrm{~m}^{-3}\right)$.

\section{Wood anatomy}

Since the wood was very hard to section, especially that of $H$. plagata, small samples were taken in the mid between pith and cambium from ethanol preserved disks and softened as described by Wagenführ (1966). The pieces were boiled for about $90 \mathrm{~min}$ in 30\% glycerine. H. plagata wood was boiled for $150 \mathrm{~min}$. Afterwards, the samples were kept in a solution of $30 \%$ glycerol, $30 \%$ ethanol in water for at least $30 \mathrm{~min}$ before sectioning.

For anatomical studies, $30-\mu \mathrm{m}$-thick cross sections and $30-\mu \mathrm{m}$-thick radial sections were cut with a sledge microtome (Reichert-Jung, Heidelberg, Germany). Sections were

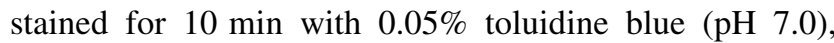


washed with Na-phosphate buffer $(0.1 \mathrm{M})$ (Robinson et al. 1987), and then mounted in $60 \%$ glycerol for microscopy. Well stained sections and a micrometer scale were photographed under a light microscope (Axioplan, Zeiss, Oberkochen, Germany) with a digital camera (Nikon CoolPix 990, Nikon, Tokyo, Japan). In cross sections of $D$. kerrii and $H$. plagata but not in those of the other species, parenchyma cells were detected after toluidine blue staining by a dark coloration that distinguished these cell types from fibers or vessels. Since parenchyma cells of all species contained starch grains, new cross sections were stained with IKI (Johansen 1940; Eschrich 1976). By this method, parenchyma cell were localized due to the presence of starch and could be quantified (see below). In addition, the presence of thin-walled cells was also used for identification of parenchyma cells.

Microphotographs of wood were analyzed with the image processing program ImageJ (Research Services Branch, National Institute of Mental Health, Bethesda, MD, USA; http://rsb.info.nih.gov/ij/) for the following parameters: mean diameter of vessel lumina (excluding the cell wall), mean lumen area per vessel, mean lumen area per fiber, fiber cell wall thickness defined as the thickness of the double wall between the lumina of two adjacent fiber cells, and area of ray parenchyma cells. To determine vessel density an area of $3.7431 \mathrm{~mm}^{2}$ was chosen and the number of all vessels in this area was counted. Fiber cross sectional lumen area was determined in an area of $0.0148 \mathrm{~mm}^{2}$ to avoid inclusion of vessels. The cell wall area was determined by ImageJ, and fiber cross sectional area was calculated as follows:

Fibre lumen area $(\%)=[($ total area - cell wall area $) /$

$$
\text { total area }] \times 100
$$

The wood anatomical terms are used in accordance with the IAWA Committee (1989).

To determine the lengths of vessel elements and fibers, the same stem segments used for cross sections were chosen. About 1-mm width of wood next to the cambium was discarded to avoid young xylem cells, and the residual wood was cut longitudinally into pieces for chemical maceration in $30 \% \mathrm{H}_{2} \mathrm{O}_{2}$ (Merck, Darmstadt, Germany) and acetic acid (Merck, Darmstadt, Germany) mixed 1:1 (after Franklin 1945 in Jansen et al. 1998). After 5 days of maceration at $60^{\circ} \mathrm{C}$, it was possible to separate the different wood elements. The macerate was then preserved in $70 \%$ ethanol for further analysis. For microscopy, the macerated wood was mounted in $60 \%$ glycerol, either unstained or stained with $0.05 \%$ toluidine blue $(\mathrm{pH} \mathrm{7.0)}$. The short lengths of vessel elements (the short distance between the perforations) were measured after the definition of Chalk and Chattaway (1934).
Predicted specific hydraulic conductance

Vessels were attributed to diameter classes with a step width of $10 \mu \mathrm{m}$. Predicted specific conductance $\left(K_{h}\right)$ was determined as $K_{h}=\Pi \sum r^{4} / 8 \eta A$, where $A=$ measuring area $\left(\mathrm{mm}^{2}\right)$ and $\eta=$ viscosity of water at $20^{\circ} \mathrm{C}(\mathrm{Pa} \mathrm{s})$ (Tyree and Zimmermann 2002). Relative contribution (\%) of vessel diameter classes to the predicted conductance (PC) was calculated as:

$\mathrm{PC}(\%)=\frac{\left[\sum r^{4}(\text { number of vessels per diameter class }) \times 100\right]}{\sum r^{4}(\text { number of all vessels })}$

Statistical analysis

Statistical analysis was performed with SAS (version 9.13, SAS Institute Inc. 2004, Cary, NC, USA) using analysis of variance (ANOVA), followed by Duncan's multiple range test. Data were indicated as means \pm SD. Differences between means were considered significant when the $P$ value of the ANOVA Duncan's multiple range test was less than 0.05. Different letters indicate significant difference. Pearson correlation coefficients were determined with the program Statgraphic Plus (Statistical Graphics Corporation, St. Louis, MO, USA).

\section{Results}

Wood density and anatomical properties

The five dipterocarp species analyzed in this study differed in wood densities in the following order $H$. plagata $>$ D. kerrii $>P$. malaanoman $>S$. almon $\approx S$. contorta (Table 1). These differences were caused by pronounced structural differences in wood anatomy (Fig. 1). The fibers of D. kerrii (Fig. 1a) and H. plagata (Fig. 1b) were very thick, almost without any lumen. Quantitative analysis showed that the fiber walls of these species were three- to four-times thicker than those of $P$. malaanoman or those of the two Shorea species (Table 1). The vessel densities of $H$. plagata were higher and the vessel diameters were smaller than those of the other species (Table 1). Correlation analysis showed that significant positive relationships existed between wood density and thickness of the fiber walls or vessel density, and a negative relationship with vessel diameter (Table 2).

Significant differences among the five species were found for vessel element lengths and fiber lengths (Table 1). D. kerrii had the longest fibers and vessel elements compared with the other species (Table 1). $H$. plagata also displayed long fibers, but relatively short vessel lengths compared with $D$. kerrii (Table 1). Analysis 
Table 1 Wood density and anatomical characteristics of vessels and fiber of five dipterocarps

\begin{tabular}{llllllll}
\hline Species & $\begin{array}{l}\text { Wood density } \\
\left(\mathrm{g} \mathrm{cm}^{-3}\right)\end{array}$ & $\begin{array}{l}\text { CW thickness } \\
(\mu \mathrm{m})\end{array}$ & $\begin{array}{l}V \text { density } \\
\left(\text { number } \mathrm{mm}^{-2}\right)\end{array}$ & $\begin{array}{l}V \text { diameter } \\
(\mu \mathrm{m})\end{array}$ & $\begin{array}{l}V \text { length } \\
(\mu \mathrm{m})\end{array}$ & $\begin{array}{l}F \text { length } \\
(\mu \mathrm{m})\end{array}$ & $\begin{array}{l}\text { Predicted } K_{\mathrm{h}} \\
\left(\mathrm{mm}^{2} \mathrm{~Pa}^{-1} \mathrm{~s}^{-1}\right)\end{array}$ \\
\hline D. kerrii & $0.70 \pm 0.06 \mathrm{c}$ & $13.77 \pm 2.89 \mathrm{~b}$ & $9.9 \pm 2.5 \mathrm{a}$ & $157.9 \pm 20.2 \mathrm{~d}$ & $459.0 \pm 29.6 \mathrm{c}$ & $778.0 \pm 57.1 \mathrm{c}$ & $11.93 \pm 3.12 \mathrm{~d}$ \\
H. plagata & $0.97 \pm 0.01 \mathrm{~d}$ & $13.94 \pm 1.28 \mathrm{~b}$ & $19.1 \pm 3.7 \mathrm{~b}$ & $96.0 \pm 8.7 \mathrm{a}$ & $378.1 \pm 62.2 \mathrm{ab}$ & $692.5 \pm 71.4 \mathrm{~b}$ & $3.92 \pm 1.36 \mathrm{a}$ \\
P. malaanoman & $0.45 \pm 0.03 \mathrm{~b}$ & $4.19 \pm 0.51 \mathrm{a}$ & $8.2 \pm 1.3 \mathrm{a}$ & $134.7 \pm 17.6 \mathrm{bc}$ & $338.4 \pm 33.5 \mathrm{a}$ & $527.3 \pm 31.5 \mathrm{a}$ & $6.88 \pm 2.28 \mathrm{bc}$ \\
S. almon & $0.38 \pm 0.03 \mathrm{a}$ & $2.93 \pm 0.20 \mathrm{a}$ & $8.9 \pm 1.6 \mathrm{a}$ & $118.8 \pm 6.4 \mathrm{c}$ & $369.4 \pm 26.7 \mathrm{ab}$ & $465.9 \pm 44.2 \mathrm{a}$ & $6.14 \pm 1.68 \mathrm{ab}$ \\
S. contorta & $0.40 \pm 0.02 \mathrm{a}$ & $4.03 \pm 0.72 \mathrm{a}$ & $9.0 \pm 1.6 \mathrm{a}$ & $151.4 \pm 10.8 \mathrm{~cd}$ & $402.5 \pm 48.1 \mathrm{~b}$ & $624.8 \pm 51.6 \mathrm{~b}$ & $9.46 \pm 2.23 \mathrm{~cd}$ \\
\hline
\end{tabular}

In each individual tree the following number of replicates was measured: vessel density $n=5$, vessel diameter $n=14$, vessel lengths $n=25$, fiber length $n=25$, and cell wall thickness $n=10$, respectively. The values followed by different letters in the same column indicate significant differences at $P \leq 0.05$. Data indicate means of $n=5$ per species $( \pm \mathrm{SD})$

$C W$ cell wall measured between the lumina of two adjacent fiber cells, $V$ vessel, $F$ fiber

of Pearson's correlation coefficients for fiber and vessel lengths with tree height revealed a positive relationship for fiber length $(P=0.001)$, but not for vessel element length $(P=0.1361)$. This is understandable, as total vessel length and not the length of the individual element is the functional character. The structure of perforation plates of the vessels may also influence water conduit. All species contained only simple perforation plates (not shown).

A closer inspection of the cross sections revealed the presence of resin canals in all species. The canals were characterized by surrounding epithelial cells, which were not lignified (see example in Fig. 1f). Their contribution to the total cross sectional area of wood was low in all species $(<1 \%)$; however, their distribution varied. In D. kerrii, they were relatively homogeneously interspersed in the secondary xylem, whereas they formed tangential bands in the other species (Rana 2008).

The wood was also composed of axial and ray parenchyma cells (Fig. 1). The axial parenchyma was observed in radial sections by vertically arranged cell files (not shown) but could also be detected in cross sections (Fig. 1c-e). In H. plagata wood, the axial parenchyma cells were mainly found surrounding the vessels (Fig. 1b), whereas in other species they formed wing-like structures occasionally connecting groups of vessels (Fig. 1a, c-e).

To analyze the wood structural composition quantitatively, the relative portions of cell wall area, vessel lumen area, fiber lumen area, ray parenchyma area and axial parenchyma area were determined. Canals were neglected because of their low abundance. The fraction of wood area occupied by ray parenchyma cells formed three groups in the five species (Fig. 2): it was high in D. kerrii, low in $P$. malaanoman and $S$. contorta and intermediate in $H$. plagata and $S$. almon (Fig. 2). The axial parenchyma fraction of $H$. plagata was significantly lower than in the other species. The area occupied by axial parenchyma showed a negative correlation coefficient with wood density (Fig. 2; Table 2).

In $H$. plagata, the species with the highest wood density, the largest area was occupied by cell walls compared with the other species (Fig. 2). For all species together, the correlation of cell wall area and wood density was highly significant (Table 2).

The secondary xylem of $D$. kerrii had the largest portion of vessel lumen area, which was significantly different from that of the remaining four species (Fig. 2). The high vessel density but low vessel diameter of $H$. plagata resulted in vessel lumen areas similar to those of $P$. malaanoman, S. almon and S. contorta (Table 1; Fig. 2).

The fiber lumen fractions in $D$. kerrii and H. plagata were significantly smaller than those from the other three species (Fig. 2) due to their very thick fiber walls (Table 1; Fig. 1). Fiber lumen area was negatively correlated with wood density (Table 2).

Distribution of vessel diameter classes and predicted conductance

The vessel diameters of 5 dipterocarps were classified into 15 classes of $10-\mu \mathrm{m}$ steps starting with the diameter class $60-70 \mu \mathrm{m}$ and the relative contribution of each diameter class to the predicted specific conductance was calculated (Fig. 3). There was considerable variation in the distribution of vessel diameter classes among the five species (Fig. 3). D. kerrii and P. malaanoman had a large range of vessel diameter classes from 60 to $210 \mu \mathrm{m}$ and from 60 to $200 \mu \mathrm{m}$, respectively (Fig. 3b, d). In contrast, the diameter ranges of $H$. plagata, $S$. almon and $S$. contorta were smaller, each showing only one diameter class 100-110, 120-130 and 170-180 $\mu \mathrm{m}$, respectively, with maximum contribution to the predicted specific conductivity (Fig. 3a, c, e).

Using these vessel diameter class distributions, the cumulative predicted conductance was calculated for each species and scaled relative to D. kerrii, which showed maximum predicted specific conductance (Table 1). The resulting curves indicate important differences in the water conduit systems of the five species. H. plagata, the species with the highest wood density, had the lowest predicted 

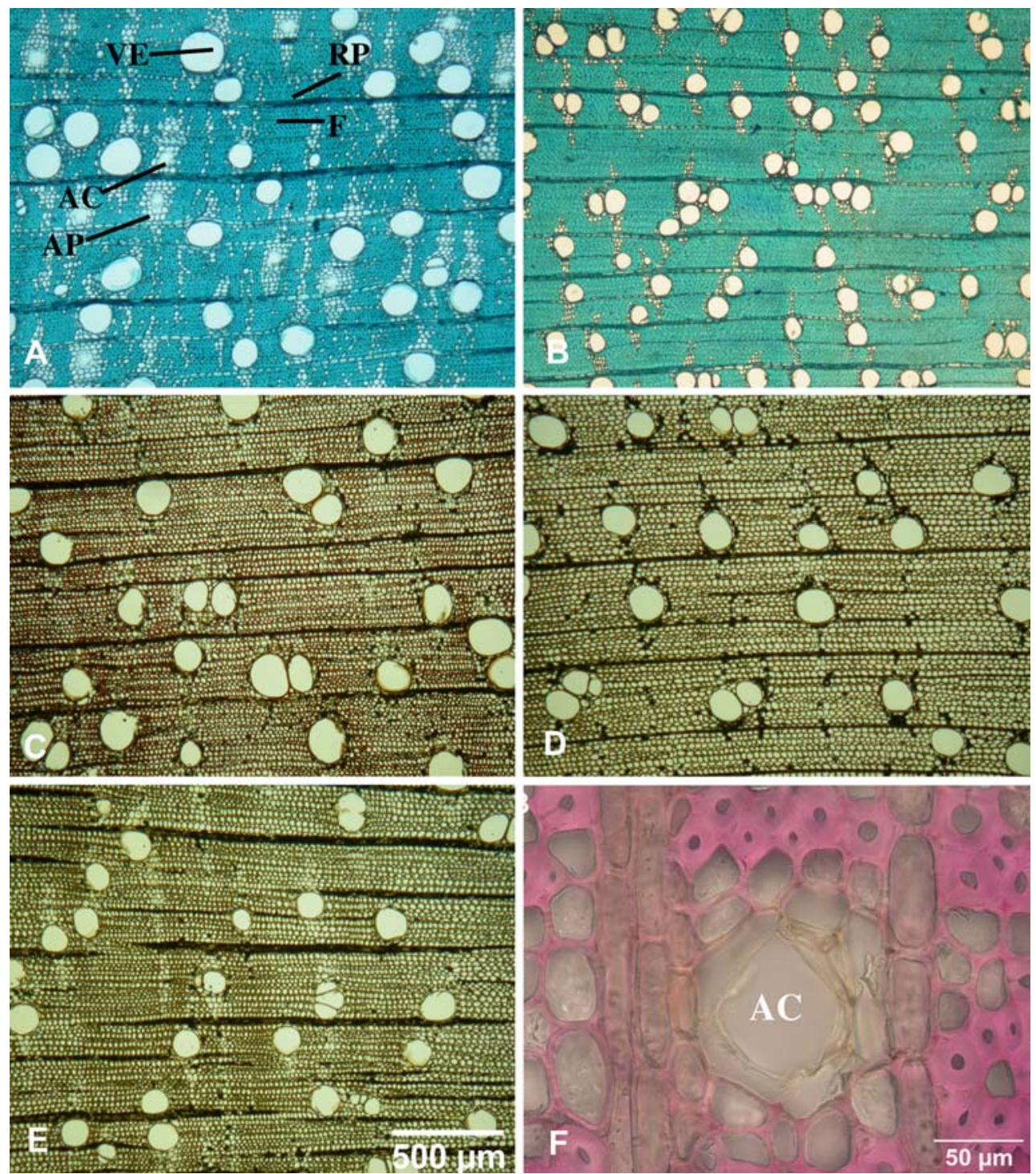

Fig. 1 Stem cross sections of five dipterocarp species. D. kerrii (a), $H$. plagata (b), P. malaanoman (c), S. almon (d) and S. contorta (e). The sections were stained with toluidine blue $(\mathbf{a}, \mathbf{b})$ or with IKI (c, d,

conductance (Fig. 3f). As the vessel diameters were shifted to higher classes in the different species, the predicted conductance increased (Fig. 3f). This relationship was highly significant (Table 2); however, the predicted specific conductance did not correlate with wood density (Table 2) because $D$. kerrii, a species with high and $S$. contorta, a species with low wood density both displayed the highest predicted conductance. The calculated maximum conductance of $S$. almon was similar to that of $P$. malaanoman (Table 1). However, for $S$. almon this value was already obtained at a smaller vessel diameter class than in P. malaanoman (Fig. 3f). The reason was that in S. almon a large number of small vessels in only two classes contributed already 27 and $24 \%$ to the predicted conductance (Fig. 3c), whereas in P. malaanoman the contribution

e). f Shows an axial canal in a cross section of $D$. kerrii after lignin staining with phloroglucinol/HCl. $A C$ axial canal, $A P$ axial parenchyma, $F$ fiber, $R P$ ray parenchyma, $V E$ vessel element

of each vessel class to total predicted conductance was always much smaller (Fig. 3d). Although predicted conductance was high in both $S$. contorta and $D$. kerrii, the latter reached high predicted values mainly by similar contributions of seven vessel classes from 130-200 $\mu \mathrm{m}$ (Fig. 3d). In contrast, in S. contorta high predicted conductance was achieved by larger numbers of smaller vessels in only four classes $(80-120 \mu \mathrm{m})$ (Fig. 3c).

\section{Discussion}

In the present study, we show that ecologically important wood traits of five selected Dipterocarpaceae differed significantly among the species. Our data on wood densities 
Table 2 Pearson correlation coefficient (PCC) between each pair of variables and estimated $P$ value

\begin{tabular}{|c|c|c|c|c|c|c|c|c|c|}
\hline & \multicolumn{9}{|l|}{ CW } \\
\hline & $V$ density & $V$ diameter & Thickness & $\mathrm{CW}$ area & VL area & FL area & $\mathrm{RP}$ area & AP area & $K_{h}$ \\
\hline W Density PCC & 0.8220 & -0.4033 & 0.8902 & 0.9762 & 0.2481 & -0.8942 & 0.4815 & -0.7320 & -0.1866 \\
\hline$P$ value & 0.0000 & 0.0456 & 0.0000 & 0.0000 & 0.2318 & 0.0000 & 0.0148 & 0.0000 & 0.3718 \\
\hline V Density PCC & & -0.6395 & 0.5798 & 0.7443 & 0.0845 & -0.6137 & 0.3372 & -0.7285 & -0.4067 \\
\hline$P$ value & & 0.0006 & 0.0024 & 0.0000 & 0.6882 & 0.0011 & 0.0993 & 0.0000 & 0.0437 \\
\hline V diameter PCC & & & -0.1333 & -0.3338 & 0.3807 & 0.1619 & -0.1119 & 0.4633 & 0.8498 \\
\hline$P$ value & & & 0.5253 & 0.1029 & 0.0604 & 0.4394 & 0.5944 & 0.0197 & 0.0000 \\
\hline CW thickness PCC & & & & 0.9205 & 0.3480 & -0.9494 & 0.6774 & -0.4771 & 0.0445 \\
\hline$P$ value & & & & 0.0000 & 0.0882 & 0.0000 & 0.0002 & 0.0159 & 0.8327 \\
\hline $\mathrm{CW}$ area $\mathrm{PCC}$ & & & & & 0.2560 & -0.9352 & 0.4990 & -0.6803 & -0.1527 \\
\hline$P$ value & & & & & 0.2167 & 0.0000 & 0.0111 & 0.0002 & 0.4663 \\
\hline $\mathrm{VL}$ area $\mathrm{PCC}$ & & & & & & -0.4849 & 0.3888 & 0.0347 & 0.6875 \\
\hline$P$ value & & & & & & 0.0140 & 0.0547 & 0.8691 & 0.0001 \\
\hline FL area PCC & & & & & & & -0.6900 & 0.4269 & -0.0542 \\
\hline$P$ value & & & & & & & 0.0001 & $\mathbf{0 . 0 3 3 3}$ & 0.7969 \\
\hline $\mathrm{RP}$ area $\mathrm{PCC}$ & & & & & & & & -0.0548 & 0.0921 \\
\hline$P$ value & & & & & & & & 0.7946 & 0.6616 \\
\hline $\mathrm{AP}$ area $\mathrm{PCC}$ & & & & & & & & & 0.2926 \\
\hline$P$ value & & & & & & & & & 0.1557 \\
\hline
\end{tabular}

Significant $P$ values with $\mathrm{P} \leq 0.05$ have been indicated with bold letters. For data see Table 1 and Fig. 2 . The variables are vessel $(V)$ density and diameter, double fiber cell wall $(\mathrm{CW})$ thickness, the relative portions of cell wall, vessel lumen, fiber $(F)$ lumen, ray parenchyma (RP) and axial parenchyma (AP) per cross sectional area and predicted conductance $\left(K_{h}\right)$

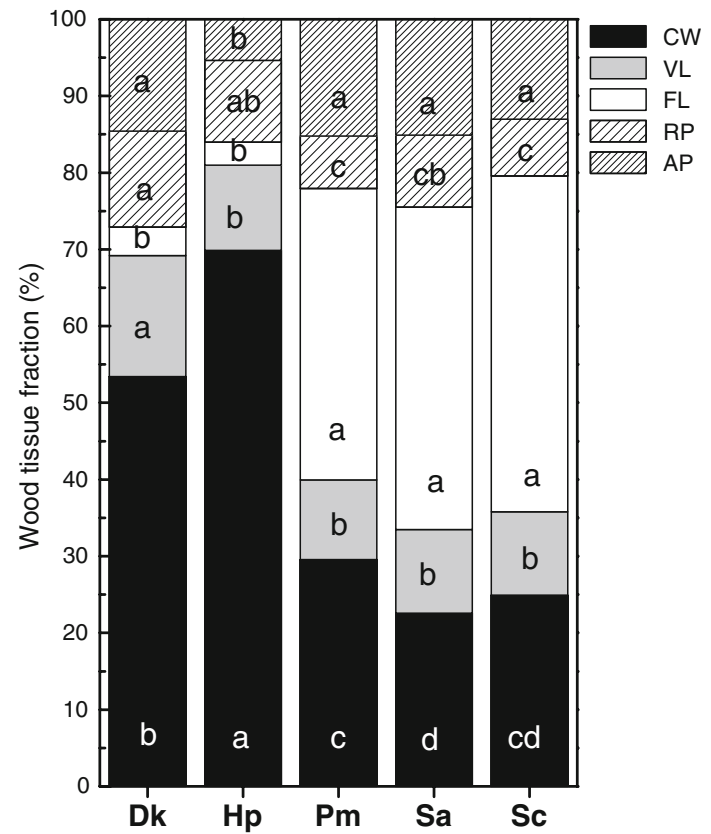

Fig. 2 Relative portion of cell wall area $(C W)$, vessel lumen area $(V L)$, fiber lumen area $(F L)$, ray parenchyma area $(R P)$ and axial parenchyma area $(A P)$. Different letters in bars indicate significant differences at $P \leq 0.05$ were in the same range as those previously reported for these species. $0.7-1.1 \mathrm{~g} \mathrm{~cm}^{-3}$ for D. kerrii, $0.8-$ $1.2 \mathrm{~g} \mathrm{~cm}^{-3}$ for H. plagata, $0.5 \mathrm{~g} \mathrm{~cm}^{-3}$ for P. malaanoman, and about $0.45 \mathrm{~g} \mathrm{~cm}^{-3}$ for the two Shorea species (Newman et al. 1996). Since carbon constitutes about $50 \%$ of the woody biomass, it can be concluded that in terms of photosynthetically assimilated carbon, the construction costs of $H$. plagata and $D$. kerrii per unit of wood volume must have been about twice those of $P$. malaanoman, $S$. almon and $S$. contorta. The high carbon demand of wood formation probably contributes to the slower growth rates of $D$. kerrii and $H$. plagata compared with the other species (Ashton 1982; Newman et al. 1996). Slow-growing species are characterized by thick-walled fibers, whereas the reverse is true for the fast-growing species (Swaine and Whitemore 1988). Similarly, van Gelder et al. (2006) showed that shade-tolerant tropical woody species had dense and tough wood to enhance survival in the understory, whereas pioneer species had low-density wood and low safety margins to enhance growth in gaps.

Resin canels have been detected in all species analyzed. In general, resins act as deterrent or have fungicidal properties (Richardson et al. 2005; Onuorah 2000), and are therefore important in shaping interactions with higher trophic levels. 
Fig. 3 Relative contribution of vessel diameter classes (step width $10 \mu \mathrm{m}$ ) to predicted conductance of the xylem of a Hopea plagata $(\mathrm{Hp})$, b Dipterocarpus kerrii (Dk), c Shorea almon ( $\mathrm{Sa}$ ), d Parashorea malaanoman $(P m)$, e Shorea contorta $(S c)$, f cumulative predicted conductance. For species comparison, the calculated predicted conductance of D. kerrii $\left(30.44 \times 10^{-3} \mathrm{~mm}^{-2}\right)$ was set as $100 \%$ and those of the other species were calculated relative to this maximum using the data from Table 1. Bars indicate means $( \pm \mathrm{SD})$
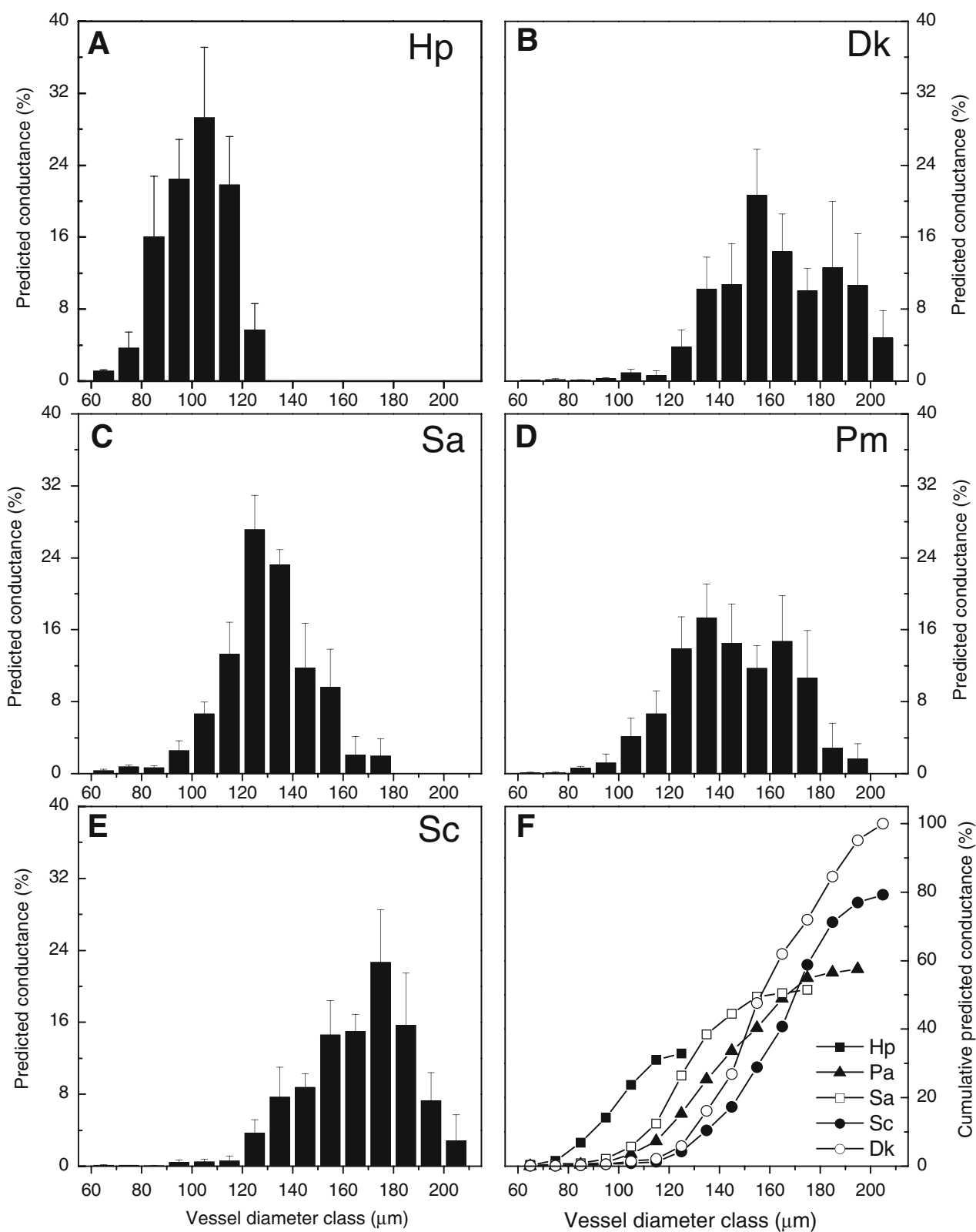

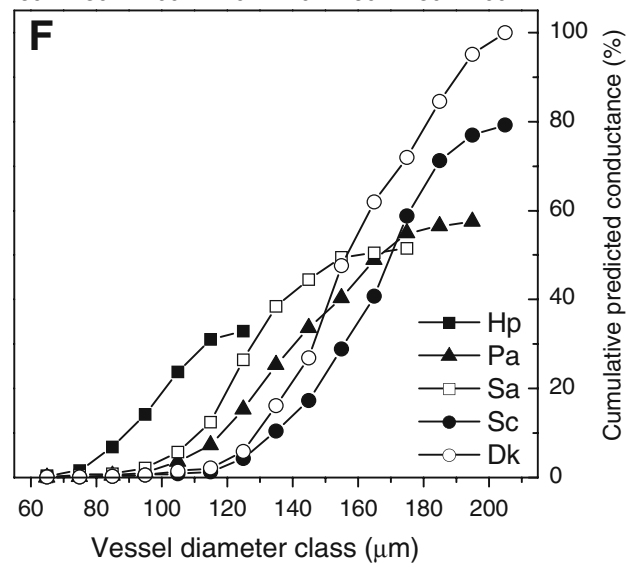

In accordance with other studies including tropical and temperate trees (Tyree et al. 1998; Hacke et al. 2000; Hacke and Sperry 2001; Swenson and Enquist 2007), wood densities were strongly correlated with occupation of the cross sectional wood area with cell walls or cell wall thickness and negatively with fiber lumen area (Tables 1, 2). A novel observation of our study was that wood densities also showed correlations with cross sectional area of parenchyma cells. Ray parenchyma which are responsible for radial nutrient transport are usually strongly lignified, may be the reason for the unexpected positive correlation coefficient between wood densities and ray cell area (Table 2). In contrast axial parenchyma, which function mainly as storage reservoir, were very thin-walled (Fig. 1).
Their cross sectional area showed a negative correlation with wood density (Table. 2). It is likely that this may decrease the mechanical strength of the wood.

Vessel diameters determine the potential hydraulic conductivity, but do not necessarily influence wood density or cavitation susceptibility (Hacke and Sperry 2001). In our study, vessel diameter was negatively correlated with wood density. Negative correlations between conductivity and wood density have previously been shown in other fastgrowing light-demanding as well as slow-growing shadetolerant tropical trees species (Christensen-Dalsgaard et al. 2007a). The light requirements of the species of our study and their influence on growth and wood properties are not known. In general, growth of Dipterocarps displays high 
plasticity and increases with light interception, although substantial unexplained variation in growth was observed (King et al. 2005). Therefore, discrepancies exist between juvenile growth and height of adult trees.

Our analysis shows that despite very similar vessel lumen cross sectional area in the investigated species, their cumulative predicted conductance varied widely (Fig. 3f). Previous studies including temperate as well as tropical tree species have shown that measured conductance correlated well with calculated values (Chiu and Ewers 1992; Ewers et al. 1989; vander Willingen et al. 2000; Christensen-Dalsgaard et al. 2007b). High mechanical resistance, required in emergent large trees with broad crowns, as well as high conductivity can be achieved by the combination of bigger vessel diameters and thick-walled fibers (Tyree et al. 1994; Alves and Angyalossy-Alfonso 2002). This combination was found here for D. kerrii, which has been reported to attain heights of more than $30 \mathrm{~m}$ (Newman et al. 1996). A tight correlation between vessel characteristics and physiological plant properties such as transpiration has been documented (Bayramzadeh et al. 2008). Therefore, our data suggest that $D$. kerrii and $S$. contorta have higher predicted water conductance and, thus, probably higher water requirements than $P$. malaanoman and $S$. almon, whereas $H$. plagata-based on this wood anatomical analysis-would be expected to be more resistant to dry periods than the other species. $H$. plagata as well as $P$. malaanoman and $S$. almon, thus, appear more suitable for restoration plantations in lowlands than $D$. kerrii and S. contorta.

Acknowledgments We are grateful to the German Academic Exchange Service (DAAD) for providing a PhD scholarship to R. Rana.

Open Access This article is distributed under the terms of the Creative Commons Attribution Noncommercial License which permits any noncommercial use, distribution, and reproduction in any medium, provided the original author(s) and source are credited.

\section{References}

Alves E, Angyalossy-Alfonso V (2002) Ecological trends in the wood anatomy of some Brazilian species. 2. Axial parenchyma, rays and fibres. IAWA J 23:391-418

Ashton PS (1982) Dipterocarpaceae. In: Van Steenis CGGJ (ed) Flora Malesiana, series I, vol 9. Martinus Nijhoff Publishers, The Hague, pp 237-552

Baas P, Ewers FW, Davis SD, Wheeler EA (2004) Evolution of xylem physiology. In: Hemsley AR, Poole I (eds) The evolution of plant physiology. Elsevier Academic Press pp 273-295

Bayramzadeh V, Funada R, Kubo T (2008) Relationships between vessel element anatomy and physiological as well as morphological traits of leaves in Fagus cretana seedlings originating from different provenances. Trees 22:217-224
Berry SL, Roderick ML (2005) Plant-water relations and fibre saturation point. New Phytol 168:25-37

Chalk L, Chattaway MM (1934) Measuring the length of vessel members. Trop Woods 40:19-26

Chiu ST, Ewers FW (1992) Xylem structure and water transport in a twiner, a scrambler, and a shrub of Lonicera (Caprifoliaceae). Trees 6:216-224

Christensen-Dalsgaard KK, Fournier M, Ennos AR, Barfod AS (2007a) Changes in vessel anatomy in response to mechanical loading in six species of tropical trees. New Phytol 176:610-622

Christensen-Dalsgaard KK, Ennos AR, Fournier M (2007b) Changes in hydraulic conductivity, mechanical properties, and density reflecting the fall in strain along the lateral roots of two species of tropical trees. J Exp Bot 58:4095-4105

Ella AB, Meniado JA (1992) Comparative wood anatomy of Philippine Dipterocarpus spp. (Apitong group). FPRDI J 21(3 \& 4):57-68

Eschrich W (1976) Strasburger's kleines botanisches Praktikum für Anfänger. Gustav Fischer Verlag, Stuttgart, p 193

Ewers FW, Fisher JB, Chiu S-T (1989) Water transport in the liana Bauhiniafassoglensis (Fabaceae). Plant Physiol 191:1625-1631

FAO 2007, ftp://ftp.fao.org/docrep/fao/009/a0773e/a0773e03.pdf, accessed in July 2008

Franklin GL (1945) Preparation on thin sections of synthetic resin and wood-resin composites, and a new maceration method for wood. Nature 155:51

Gottwald H, Parameswaran N (1966) Das sekundäre Xylem der Familie Dipterocarpaceae, anatomische Untersuchungen zur Taxonomie und Phylogenie. Bot Jahrb Syst Pflanzengesch Pflanzengeogr 85:410-508

Hacke UG, Sperry JS (2001) Functional and ecological xylem anatomy. Perspectives in plant ecology, evolution and systematics 4(2):97-115

Hacke UG, Sperry SJ, Pittermann J (2000) Drought experience and cavitation resistance in six shrubs from the great Basin, Utah. Basic Appl Ecol 1:31-41

Hacke UG, Sperry JS, Pockman WT, Davis SD, McCulloh KA (2001) Trends in wood density and structure are linked to prevent of xylem explosion by negative pressure. Oecologia 126:457-461

Hacke UG, Sperry JS, Wheeler JK, Castro L (2006) Scaling of angiosperm xylem structure with safety and efficiency. Tree Physiol 26:689-701

IAWA Committee (1989) IAWA list of microscopic features for hardwood identification. IAWA Bull 10:219-332

IUNC (2007) http://www.iucnredlist.org/search/search-basic. Accessed July 2007

Jacobson AL, Ewers FW, Pratt RB, Paddock WA, Davis SD (2005) Do xylem fibres affect vessel cavitation resistance? Plant Physiol 149:546-556

Jansen S, Kitin P, De Pauw H, Idris M, Beeckman H, Smets E (1998) Preparation of wood specimens for transmitted light microscopy and scanning electron microscopy. Belg J Bot 131:41-49

Johansen AD (1940) Plant microtechnique. McGraw-Hill, New York, p 201

Ketterings QM, Coe R, van Noordwijk M, Ambagau Y, Palm CA (2001) Reducing uncertainty in the use of allometric biomass equations for predicting above-ground tree biomass in mixed secondary forests. For Ecol Manage 146:199-209

King DA, Davies SJ, Nur Supardi MN, Tan S (2005) Tree growth is related to light interception and wood density in two mixed dipterocarp forests of Malaysia. Funct Ecol 19:445-453

Langenberger G (2003) Diversität, Struktur und Reliefabhängigkeit der Vegetation in einem Tieflandregenwald der Insel Leyte, Philippinen. Dissertation, Institut für Pflanzenproduktion und Agrarökologie der Tropen und Subtropen, Universität Hohenheim 
Langenberger G (2006) Habitat distribution of dipterocarp species in the Leyte Cordillera: an indicator for species-site suitability in local reforestation programme. Ann For Sci 63:149-156

Lomibao BA (1973) Guide to the identification of the woods of Philippine Dipterocarpaceae. Magazine for forest products research and industries development (FORPRIDE digest) 2:2634

Myers N, Mittermeier RA, Mittermeier CG, da Fonseca GAB, Kent J (2000) Biodiversity hotspots for conservation priorities. Nature 403:853-858

Newman MF, Burgess PF, Whitemore TC (1996) Manuals of dipterocarps for foresters, Philippines. Center for International Forestry Research, Jakarta, pp 47-53

Onuorah EO (2000) The wood preservative potentials of heartwood extracts of Milicia excelsa and Erythrophleum suaveolens. Bioresour Technol 75:171-173

Preston KA, Cornwell WK, DeNoyer JL (2006) Wood density and vessel traits as distinct correlates of ecological strategy in 51 California coast range angiosperms. New Phytol 170:807-818

Rana R (2008) Correlation between anatomical/chemical wood properties and genetic markers as a means of wood certification. Dissertation, Klartext GmbH, Göttingen, ISBN 978-3-9811503$2-2$

Richardson DP, Messer AC, Greenberg S, Hagedorn HH, Meinwald J (2005) Defensive sesquiterpenoids from a dipterocarp (Dipterocarpus kerrii). J Chem Ecol 15:731-747

Robinson DG, Ehlers U, Herken R, Herrmann B, Mayer F, Schürmann F-W (1987) Methods of preparation for electron microscopy. An introduction for biomedical sciences. Springer, Berlin, p 189. ISBN 3-540-17592-X
Slik WF (2004) El Niño droughts and their effects on tree species composition and diversity in tropical rain forests. Oecol 141:114-120

Swaine MD, Whitemore TC (1988) On the definition of ecological species groups in tropical forests. Vegetatio 75:81-86

Swenson NG, Enquist BJ (2007) Ecological and evolutionary determinants of a key plant functional trait: wood density and its community-wide variation across latitude and elevation. Am J Bot 94:451-459

Tyree M, Zimmermann MH (2002) Xylem structure and the ascent of sap. Springer-Verlag, New York

Tyree MT, Davis SD, Cochard H (1994) Biophysical perspectives of xylem evolution: is there a tradeoff of hydraulic efficiency for vulnerability to dysfunction? IAWA J 15:335-360

Tyree MT, Patiño S, Becker P (1998) Vulnerability to droughtinduced embolism of Bornean heath and dipterocarp forest trees. Tree Physiol 18:583-588

van Gelder HA, Poorter L, Sterck FJ (2006) Wood mechanics, allometry, and life-history variation in a tropical rain forest tree community. New Phytol 171:367-378

vander Willingen CV, Sherwin HW, Pammenter NW (2000) Xylem hydraulic characteristics of subtropical trees from contrasting habitats grown under identical environmental conditions. New Phytol 145:51-59

Wagenführ R (1966) Anatomie des Holzes. VEB Fachbuchverlag Leipzig, pp 156-159

Westoby M, Wright IJ (2006) Land plant ecology on the basis of functional traits. Trends Ecol Evol 21:261-268

Wood density database http://www.worldagroforestrycentre.org/sea/ Products/AFDbases/WD/. Accessed July 2008 